
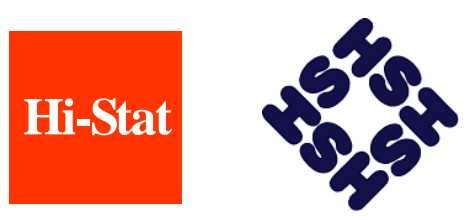

Discussion Paper Series

No.60

Determinants of high-royalty contracts and the impact ofstronger protection of intellectual property rights in Japan

Sadao Nagaoka

December 2004

Hitotsubashi University Research Unit for Statistical Analysis in Social Sciences A 21st-Century COE Program

Institute of Economic Research Hitotsubashi University Kunitachi, Tokyo, 186-8603 Japan http://hi-stat.ier.hit-u.ac.jp/ 


\title{
Determinants of high-royalty contracts and the impact of stronger protection of intellectual property rights in Japan
}

\author{
Sadao Nagaoka \\ Institute of Innovation Research, Hitotsubashi University, 2-1 Naka Kunitachi Tokyo 186-8603 Japan
}

\begin{abstract}
$\overline{\text { Nagaoka, Sadao - Determinants of high-royalty contracts and the impact of stronger protection }}$ of intellectual property rights in Japan

This paper first reviews how Japan has strengthened the protection of intellectual property rights (IPRs), focusing on the expansion of the patentable subject matter, the restriction of the possibility of compulsory licensing, stronger deterrence against infringement and the introduction of the doctrine of equivalents. Second, based on the statistical analysis of sector-level panel data, it shows that

(1) R\&D intensity of domestic industry, trademark licensing, cross-licensing and, to a smaller degree, monopoly provisions are the significant determinants of the incidence of high-royalty contracts, and

(2) Stronger protection of intellectual property rights looks to have increased the incidence of high-royalty contracts in the latter part of 1990s in the Japanese industries for which patent is important for appropriability.
\end{abstract}

JEL classification: $\mathrm{F} 23, \mathrm{O} 34$

Keywords: Intellectual property rights; Licensing contract; Appropriability; Patent

\section{Introduction}

Intellectual property rights (IPRs) protection in Japan has been significantly strengthened since the mid-1990s. This policy shift has certainly reflected international developments, in particular, the IPRs policy dialogue between the Japanese and the U.S. governments in the framework of the Structural Impediments Initiative that culminated in the agreement in 1994, and the Trade Related Intellectual Property Rights (TRIPs) agreement in 1995. It also reflected the recognition by the Japanese policy makers of the increasing importance of intellectual property in the economy in which investments in intangibles had become very important.

This paper reviews such policy changes in Japan and attempts to evaluate their impact, focusing on the incidence of the high-royalty technology import contracts in Japan. More

E-mail address: nagaoka@iir.hit-u.ac.jp 
specifically, I examine whether the fraction of high royalty contracts has increased more in those sectors where patents play an important role in appropriating the return from R\&D. In addition, I also inquire how this fraction is related to basic contract characteristics such as exclusive rights, cross licensing provisions, and the structure of IPRs specified in the contracts. Although these are straightforward questions to ask, they are still important ones, given that empirical studies of the determinants of licensing contracts are scarce. ${ }^{1}$

In what follows, Section 2 reviews Japanese policy, focusing on the expansion of patentable subject matter, restriction of the possibility of compulsory licensing, stronger deterrence against infringement and the introduction of the doctrine of equivalents. Section 3 provides a brief overview of the major features of technology import contracts in Japan. Section 4 provides an analytical framework, and Section 5 provides the framework for the empirical analysis. Section 6 provides empirical results, and Section 7 concludes and discusses the implications.

\section{Stronger intellectual property rights protection in Japan}

\subsection{Three driving forces for the changes}

The Japanese government has significantly strengthened the protection of intellectual property rights (IPRs) since the early 1990s. The first major driving force for such changes was the TRIPs agreement in 1995. It requires member countries, among others, to make patent protection available for any inventions, whether products or processes, in all fields of technology, with only a few specified exceptions and to make the term of protection available for not less than a period of twenty years counted from the filing date.

\footnotetext{
${ }^{1}$ Some important empirical studies of licensing include: Taylor and Silberston (1973), Caves, Crookell and Killing (1983), Davidson and McFeridge (1984), Anand and Khanna (2000) and Arora, Fosfuri and Gambardella ( 2001).
} 
The second driving force was the U.S.-Japan agreement in 1994, under which both governments agreed to undertake three measures, respectively. The Japanese government switched to the post-grant opposition system from the pre-grant opposition system in 1994, and then unified the opposition system with the patent validity examination system in 2004. It also pledged not to invoke compulsory licensing to resolve the blocking relationship (Article 92) unless it is for the purpose of correcting anticompetitive conduct or for the public or non-commercial use (see the following subsection for more details). Furthermore, it reformed the early examination system to allow an applicant with an application to a foreign patent office to enjoy a fast track in examination. ${ }^{2}$ These measures are applicable to domestic as well as to all foreign patent applicants, due to the MFN requirement of the TRIPS.

The third driving force was the domestic reform initiative in recognition by the Japanese policy makers of the increasing importance of the intellectual property system in the economy in which investments in intangibles have become important. Table 1 shows the share of investments in intangible and tangible assets by major Japanese corporations in $2000 \mathrm{FY}$ on the non-consolidated basis. R\&D investment overwhelms plant and equipment investment in the pharmaceutical industry as well as in the game and telecommunications industry. Even in the automobile industry, $R \& D$ investment is significantly larger than investment in plant and equipment on the non-consolidated basis. Furthermore, advertisement investment is as important as plant and equipment investment in the pharmaceutical and game industry.

(Table 1)

\footnotetext{
${ }^{2}$ The U.S. government pledged the following three measures: introduction of an early disclosure system of patent application, introduction of a re-examination system, and continued forbearing using compulsory licensing.
} 


\section{2 Expansion of the patentable subject matter}

One of the major changes in the scope of patent protection in the 1990s was the patentability of computer programs. Although the issue of whether an algorithm or mathematical formula can be patented was also important in the United States, the issue there was resolved in early 1980s in favor of its patentability. ${ }^{3}$ A major constraint in Japan was that the patent law defines an invention eligible for patent as a "technical idea utilizing natural laws." ${ }^{4}$ Reflecting this qualification, a computer program was not patentable until 1993, unless it was combined with hardware. By itself, it became patentable in 1997, when recorded in a computer-readable storage medium. It became fully patentable in 2000 (affirmed in 2002 patent law amendment, although the legal definition of a patent was not modified).

The increasing patentability of software seems to have been reflected in the increasing proportion of patent rights incorporated in the contracts of technology imports of Japanese firms. According to Figure 1, only less than $1 \%$ of the contracts specified patent rights in software licenses, compared to more than $60 \%$ for the hardware technology licenses in 1990 . The proportion of contracts with patents in software licenses increased significantly in the 1990s. It reached $22.6 \%$ of the contracts in 1998 .

(Figure 1)

\subsection{Restriction of the possibility of compulsory licensing}

Based on the U.S.-Japan Agreement in 1994, the Japanese Government made it clear that it would not require compulsory licensing in order to resolve the blocking relationship (based on Article 92), unless it was for the purpose of correcting anticompetitive conduct or for public or

\footnotetext{
${ }^{3}$ Diamond v. Diehr, Supreme Court of the United States, 450 U.S. 175, 1981.

${ }^{4}$ Merges (1996) suggests that weak copyright and patent protection of software in Japan retarded the development of the prepackaged software industry in Japan, since the protection of IPR by contractual means is not effective for prepackaged software, unlike custom software.
} 
non-commercial use. ${ }^{5}$ Such a blocking relationship can occur for example between a basic patent and an improvement patent, and is usually settled privately though unilateral or cross license. However, if a licensor refuses to give a license or demands a large royalty, a potential licensee might ask the government to intervene under Article 92. Although there was not a single case of the government actually ordering a compulsory license, there were at least 23 applications that were later privately settled. Many of these applications were made by pharmaceutical companies.

The threat of a government intervention itself has the effect of reducing the royalty rate on the blocking patent. Thus, the commitment by the Government not to intervene would have the effect of increasing the royalty rate. Figure 2 shows the royalty payments for patent licensing and the R\&D investments of major Japanese pharmaceutical firms, both relative to sales, for the 1980s and 1990s. While the R\&D sales ratio has continued to rise, the ratio of patent royalty to sales declined until the middle of the 1990s and thereafter has risen. The ratio of royalty payment to $R \& D$ also started to rise, reversing the downward trend from the mid-1990s. The reversal of trend indicates a possibility that stronger protection of patents in Japan, including the restriction of the possibility of compulsory licensing, has affected the royalty rate.

(Figure 2)

\subsection{Stronger deterrence against infringement}

Deterrence against infringement has also been significantly strengthened by the reform of the private damage system as well as by stronger criminal sanctions. The damage awarded in the case of infringement used to be low in Japan. In addition to the difficulty in proving the causal

\footnotetext{
5 This commitment goes beyond the agreement of TRIPs (Article 31 Other Use Without Authorization of the Right Holder), which allows more extensive interventions, except in the case of semi-conductor technology.
} 
link between infringement and lost profit, the opportunity cost was not used in estimating the lost profit. The patentee would incur only the incremental cost to achieve the output that he would be able to produce if there were no competing entry infringing his patent. Despite this, average cost was used in determining the lost profit due to such infringement, significantly underestimating the damage. The court rulings, however, have begun to adopt the concept of opportunity cost since the middle of $1990 \mathrm{~s}^{6}$

A similar problem existed in the determination of royalty as damage. When the causality between infringement and damage is not proven, the damage is estimated based on the royalty. The basis of such royalty, however, used to be a reference rate such as the royalty rate of a state-owned patent, partly because the patent law provision on damage (Article 102) used to characterize it as "the value to be ordinarily received." Thus, it was not based upon the hypothetical ex-ante royalty negotiation between the two parties as in the United States, which could reflect the profit made by the infringing firm.

The patent law was revised in 1988. The amendment introduced a new provision that allows the patentee to presume the amount of damages due to infringement, based on the sales made by the infringer and on the profit rate of the patentee. It also dropped the term "usual" in its stipulation of the royalty damage. Furthermore, it strengthened the criminal sanctions. Similar amendments with a view to strengthening deterrence were introduced for the copyright law and for the law on fair competition that protects know-how.

The effect of stronger enforcement looks to be clearly observable in the decline of the "piracy" rate of business software. Figure 3 shows the business software "piracy" rates in seven major industrialized countries as estimated by the Business Software Alliance. The "piracy" rate

\footnotetext{
${ }^{6}$ The first case articulating the use of incremental cost in calculating the lost profit was the 1995 decision by Tokyo Local Court, involving the infringement of copyright of a computer program.
} 
in the Japan was among the highest in 1994, together with that of Italy, more than twice the U.S. rate. However, Japan's rate declined significantly over the following eight years, reaching a similar level as that of Germany in 2002.

(Figure 3)

\subsection{Introduction of the doctrine of equivalents}

Another important development was the affirmation of the "doctrine of equivalents" by the Supreme Court in 1998. The strength of patent protection critically depends on how broadly the court recognizes equivalence, since it determines how much a firm has to spend to invent around an existing patent. The Supreme Court ruled, among other things, that "equivalence" should be determined based on the technologies available when the infringement takes place, not when the patent is granted. Thus, the modifications that are obvious given the technologies available at the time of infringement keep equivalence. After this ruling, 140 litigations involving the issue of equivalence were initiated from 1998 to 2003, and equivalence was recognized by the courts in 15 cases in this period.

\section{Brief overview of the licensing contracts for technology import}

In the rest of this paper, I analyze whether we can detect the effect of stronger protection of IPRs in Japan on the price of technology, in particular, on the price of imported technology. Since we use industry-level data, we can analyze only the aggregate characteristics of licensing contracts, preventing us from analyzing the effects of firm-level factors on royalty terms. On the other hand, the survey used is very comprehensive, based on a compulsory reporting system. In addition, it has a long time horizon, so that we can use panel estimation in investigating the above questions (See Table A-1 in the appendix for details). 
The number of technology import contracts was 2,000-3,000 annually, during the period from 1971 to 1998 (see Figure 4). The number of contracts dropped sharply in 1998, due to reduction in the scope of the reporting requirements. ${ }^{7}$ There has been a significant change in the composition of imported technologies. Most importantly, the share of software technology has increased significantly over time. It accounted for less than $10 \%$ in 1981 , but for about a half in the 1990s. The change in the aggregate picture of contract characteristics over time has also been closely related to this structural change.

(Figure 4)

Let us summarize the changes in contract characteristics in both price and non-price terms over the last two decades. Table 2 shows two averages: the simple average of all contracts in the columns under group I, and the average of the values of 48 industries in the columns under group II. The latter average controls the structural change of industry in terms of the number of contracts due to its fixed weight. For the first average, $94.5 \%$ of the contracts involve financial payments, and $62.2 \%$ have royalty provisions. Some $26.5 \%$ of the royalty contracts have high royalty rates ( $8 \%$ or more of sales) and $61.3 \%$ have initial payment provisions in the most recent period.

\section{(Table 2)}

The average price of imported technology has increased during these two decades, although its extent is not large once we control for the change in the composition of imported technologies. The share of high royalty contracts increased significantly from $13.4 \%$ in 1981-84 to $26.5 \%$ in $1995-98$. However, the increase is much less substantial, once we control for structural change. It increased only from $13.4 \%$ in $1981-84$ to $14.8 \%$ in $1995-98$, according to

\footnotetext{
7 The reporting requirement was narrowed down to the contracts with total payments more than 30 million Yen.
} 
the second average. The share of the contracts with initial payments and the share of the contracts with financial payments also increased from $57.6 \%$ to $60.4 \%$ and from $93.3 \%$ to $95.9 \%$, respectively, according to the second average.

As for non-price conditions (exclusive territorial provisions (or monopoly provisions), and cross-licensing), the share of the contracts with monopoly rights declined from $51.0 \%$ in 1981-1984 to $29.4 \%$ in the most recent period in the total average, and declined from $52.0 \%$ to $41.6 \%$ according to the second average. Cross-licensing became more prevalent only according to the second average, from $4.4 \%$ to $5.6 \%$.

Table 3 shows the structure of intellectual property rights (IPRs) specified in the licensing contracts over the last two decades. Know-how is most frequently specified in the contracts. Close to $50 \%$ of the contracts specified only know-how in these periods. More than $70 \%$ of the contracts specified know-how as one of the IPRs in 1995-98. Although it is often pointed out that know-how is difficult to trade due to information asymmetry, ${ }^{8}$ it is an important part of licensing. Trademarks have become more often specified. The frequency of contracts with only trademarks increased significantly from $5.9 \%$ in $1981-84$ to $19.4 \%$ in $1995-98$. Some $32.4 \%$ of the contracts covered trademarks in 1995-98. Patents have become less specified according to the first average. The frequency of contracts with only patents declined from $11.7 \%$ in $1981-84$ to $9.0 \%$ in 1995-98. However, this is entirely due to the structural change in the composition of imported technologies, since no decline is recorded based in the second average. Some $24.0 \%$ of the contracts specified patents in the 1995-98 period.

(Table 3)

\footnotetext{
${ }^{8}$ See Arrow (1962) for a seminal discussion.
} 


\section{Theoretical framework}

The theoretical framework for the determination of royalty in licensing contracts is as follows. A licensor (X) and a licensee (Y) negotiate a licensing contract based on the Nash bargaining framework. We first consider the case of a bilateral monopoly and later discuss the extension. We denote the threat point for such negotiation by $\left(\Pi_{M}^{X}, \Pi_{M}^{Y}\right)$, where $\Pi_{M}^{X}$ and $\Pi_{M}^{Y}$ are the levels of the profits of the licensor and the licensee respectively, when the license does not take place (Subscript $M$ indicates that technology is used only by the licensor). If licensing takes place, the licensor and the licensee obtain the profit $\Pi_{D}^{X}$ and $\Pi_{D}^{Y}$ respectively, both of which are the profits before the transfer of licensing fees (Subscript D indicates that technology is licensed).

The Nash bargaining solution gives the following gain to the licensor:

$$
\theta\left\{\left(\Pi_{D}^{X}+\Pi_{D}^{Y}\right)-\left(\Pi_{M}^{X}+\Pi_{M}^{Y}\right)\right\}
$$

where $\theta(0<\theta<1)$ represents the bargaining power of the licensor. Thus, the licensee has to pay the following royalty $\mathrm{R}$ to the licensor:

$$
R=\theta\left\{\left(\Pi_{D}^{X}+\Pi_{D}^{Y}\right)-\left(\Pi_{M}^{X}+\Pi_{M}^{Y}\right)\right\}+\Pi_{M}^{X}-\Pi_{D}^{X}=\theta\left(\Pi_{D}^{Y}-\Pi_{M}^{Y}\right)+(1-\theta)\left(\Pi_{M}^{X}-\Pi_{D}^{X}\right)
$$

If we assume that the licensee $\mathrm{Y}$ does not use its technology in the market of the licensor $\mathrm{X}$, this can be simplified into the following:

$$
R=\theta\left(\Pi_{D}^{Y}-\Pi_{M}^{Y}\right)
$$

The payment is high when the licensee $\mathrm{Y}$ can realize high profit using the licensed technology (a higher $\Pi_{D}^{Y}$ ), and when he can realize only low profit without licensing (a lower $\Pi_{M}^{Y}$ ).

The profit that $\mathrm{Y}$ can realize using the licensed technology depends on the possibility of competition from domestic imitation. For simplicity, we assume that $\mathrm{Y}$ cannot make a positive profit if imitation takes place, the probability of which is given by $\gamma$. If we denote the profit of $Y$ with no competition from imitation by $\Pi_{D, N}^{Y}$, we have 


$$
\Pi_{D}^{Y}=(1-\gamma) \Pi_{D, N}^{Y}
$$

In case $\mathrm{Y}$ cannot obtain a license, he can still realize some profit by doing his own R\&D. In particular, it is assumed that

$$
\Pi_{M}^{Y}=(1-\delta) \Pi_{D}^{Y}-\alpha R D^{X},
$$

where $R D^{X}$ is the amount of $\mathrm{R} \& \mathrm{D}$ expenditure, which $\mathrm{X}$ spends to invent around that technology. The parameters $\delta$ and $\alpha$ indicate the difficulty of inventing- around. Combining the above three equations, we have

$$
R=\theta\left\{\delta(1-\gamma) \Pi_{D, N}^{Y}+\alpha R D^{X}\right\}
$$

Equation (5) suggests the following four determinants of the price of technology $(R)$. First, $R$ is high when the licensed technology enables the licensee to realize high profit, in particular, when the technology is advanced relative to prevailing technology, the technology licensed is comprehensive or highly developed so that its commercialization does not need a large additional expenditure. Second, if the technology to be licensed requires a large R\&D expenditure for being invented around, the royalty rate would be high.

Third, $R$ would increase with stronger IPR protection, due to smaller vertical competition for the licensor from the licensee as well as to smaller horizontal competition for the licensee. Since stronger protection of IPRs makes inventing-around difficult and expensive (i.e., $\delta$ and $\alpha$ are large), it shifts the threat point in favor of a licensor. ${ }^{9}$ In addition, it makes imitation more difficult ( $\gamma$ is low), so that the infringement by a third party is reduced. Both of these changes increase the payment for the technology.

Fourthly, it depends on the bargaining power of the licensor. If ex-ante competition

\footnotetext{
${ }^{9}$ However, there is a theoretical possibility that stronger protection of IPRs shifts the threat point in favor of a licensee. As discussed by Schankerman and Scotchmer (1999), larger damage for infringement can induce a licensee to switch its conduct from the strategy of infringement (and payment of damage) to that of non-infringement when it faces refusal of license.
} 
among licensees is strong so that the entire bargaining surplus belongs to a licensor, we have $\theta=1$ so that

$$
R=\delta(1-\gamma) \Pi_{D, N}^{Y}+\alpha R D^{X}
$$

A good indicator of ex-ante competition is exclusivity provision, since, if there is strong ex-ante competition among licensees, a licensee would not be willing to invest in commercializing the technology unless he were guaranteed by a licensor for an exclusive entry. Thus, we would expect that the royalty rate would be high when the licensing contract has an exclusivity provision.

If the effect of competition among licensors is so strong that the entire bargaining surplus belongs to a licensee due to the competition among licensors with identical technology, we have the following:

$$
R=0
$$

In this case, the exogenous changes affecting the ex-post profits of a licensee, including the level of protection of intellectual property rights, do not affect the price of technology. In reality, however, it is unlikely that competition among licensors is so severe, since patent protection restricts the possibility that two firms have exactly the same technology.

In the empirical analysis, we depend on the data of royalty rates, which are given in terms of the ratio relative to the sales of the licensee $\left(S_{D}^{Y}\right)$. If we assume that all payments are made by a running royalty and that it does not affect the sales of a licensee, ${ }^{10}$ we obtain the following expression for the royalty rate:

$$
\text { Rate }=R / S_{D}^{Y}=\theta\left\{\delta(1-\gamma)\left(\Pi_{D, N}^{Y} / S_{D}^{Y}\right)+\alpha\left(R D^{X} / S_{D}^{Y}\right)\right\}
$$

\footnotetext{
${ }^{10}$ Such would be the case if the licensee faces Bertrand competition in the product market. In this case his price is entirely determined by the product quality or cost of the competitor with the second-best technology.
} 
One noteworthy point is that the reduced possibility of third party infringement (lower $\gamma$ ) can reduce the royalty rate due to the expansion of sales $\left(S_{D}^{Y}\right)$, if the second term in the bracket is important. This reflects that a part of the payment for technology depends on the threat point, so that it declines relative to the realized sales when the latter increases.

\section{Framework of estimation}

We postulate the following specification in order to examine how the royalty rates are related to the contract characteristics, as suggested by the above theoretical model, based on industry-level panel data:

$$
\begin{aligned}
& (\text { price })_{i, t}=\alpha+\beta_{1}(\text { rds })_{i, t}+\beta_{2}(\text { monopoly })_{i, t}+\beta_{3}(\text { br })_{i, t}+\beta_{4}(\text { pat })_{i, t}+\beta_{5}(k h)_{i, t}+\beta_{6}(\mathrm{cr})_{i, t} \\
& +\beta_{7}(\text { initial })_{i, t}+\beta_{8}(\text { propd })_{i, t}+\eta_{i}+\delta_{\mathrm{t}}+\varepsilon_{i, t}
\end{aligned}
$$

In the above specification, $i$ denotes the sector and $t$ the time period. The variable $\eta_{i}$ is industry fixed effects. We introduce 31 industry dummies to control industry-level missing variables, which are fixed over time and may cover research opportunities, demand growth and market structure. For example, we expect that a sector with rich research opportunities would have high level of R\&D as well as high royalty rates, so that we may find spurious correlations between the two variables unless we control for industry fixed effects. We divide the 20 year time period into the following four periods: 1981 to $1984 ; ; 1985,1986$ and $1989 ; 1990$ to 1994 ; and 1995 to 1998. We introduce time dummies $\delta_{t}$ (Time2, Time3, Time4), which will absorb the common effect of the stronger intellectual rights protection on royalty rates, thus making it more difficult to identify the effect of stronger IPR policy. But this can control for the effects of macroeconomic changes on royalty rates. Finally $\varepsilon_{i, t}$ is a random term.

The dependent variable (price) $)_{i, t}$ is the price of technology. We use the share of the 
licensing contracts with the royalty rate of $8 \%$ or more in all royalty based contracts (price), to measure the price level of imported technology. The variance of this variable is likely to be heterogeneous, given the difference in the number of contracts with royalty payments across sectors. We use GLS estimation to take this into account. We also limit our sample to those industries with ten or more licensing contracts with royalty payments in each period (we have 39 sectors satisfying this condition out of 48 sectors (see Table A-2), and the sample is further limited to 32 sectors, due to the availability of $R \& D$ data. Table A-3 in the appendix provides summary statistics.

The first independent variable $(r d s)_{i, t}$ is the R\&D intensity of domestic industry: the R\&D expenditure of each industry divided by its sales in each period. It aims at capturing the profitability of commercializing imported technology as well as the cost of R\&D necessary for a licensee to invent around the technology in case licensing does not materialize. As suggested by equations (6) and (8), it would positively affect the royalty rates.

The second independent variable (monopoly) $)_{i, t}$ is the share of the contracts with exclusive right. The presence of the exclusivity provision shows the existence of ex-ante competition among licensees, as explained above. It would positively affect royalty since it implies a stronger bargaining power of a licensor. ${ }^{11}$ The third, fourth and fifth independent variables indicate the structure of intellectual property rights (IPRs) specified in contracts. The variables $b r, p a t$ and $k h$, respectively, denote the share of the contracts with trade-mark, patents and know-how. The coefficient of each variable shows the marginal value of each IPR, so that it should be positive.

The sixth independent variable $(\mathrm{cr})_{i, t}$ is the share of the contracts with a cross licensing provision. Higher incidence of cross-licensing in the context of technology import implies that

\footnotetext{
11 The exclusivity provision may also indicate the quality of technology, since a licensor is more concerned with preventing competition among licensees when the technology is dominant over the prevailing technology.
} 
more payment is made in kind (i.e., by technology), and therefore the smaller need for paying a high royalty. However, it may also indicate higher quality of the technology introduced in the sector, since the patentee of a pioneer patent often requires the grant-back of its derivative technologies. The seventh independent variable $(\text { initial })_{i, t}$ is the share of the contracts with initial payment. The total payment for technology consists of royalty payments and initial payments. The variable initial controls for the substitutability between initial payments and royalty payments.

The last independent variable (propd $)_{i, t}$ is a dummy variable for the period from 1994 to 1998 , representing the effect of the stronger IPR policy is Japan since the mid-1990s. We evaluate whether the incidence of high royalty contracts increased in 1994-1998 in a manner consistent with the impact of stronger IPRs. There are two important sources for the variation of the effects of stronger IPR across sectors: the effectiveness of IPR on the appropriability of R\&D and the territorial restriction stipulated in the licensing contracts with respect to the Japanese market. As for the indicator of the contribution of IPRs to appropriability, we use two variables. One indicator (aprd) is the appropriability indicator of patent protection (apr), which is based on the survey results of Goto and Nagata (1996), ${ }^{12}$ multiplied by the time dummy variable (Time4). We expect that stronger IPR protection would affect more the sector for which the contribution of a patent to the appropriability of $R \& D$ is stronger. The second indicator $(r d s d)$ is the $R \& D$ intensity of each sector ( $r d s$ multiplied by the time dummy (Time4)). Stronger protection of IPR (larger $\alpha$ ) has a larger effect on the royalty in R\&D intensive industry as shown in equations (6) and (8).

The effects of stronger IPR protection would also depend upon the territorial scope of

\footnotetext{
${ }^{12}$ See the appendix for further explanation. Cohen, Nelson and Walsh (2000) present the results of the most recent survey for the U.S. industry.
} 
licensing contracts. If licensing covers only the Japanese market, its term is strongly influenced by the IPR protection in Japan. The variable we use is the average percentage of licensing contracts with its territorial scope restricted to Japan from 1990 to 1991 ( $m r k j$, see Table A-2 in the Appendix for the variation of this variable across sectors), multiplied by the time dummy variable, i.e., $m r k d=m r k j *$ Time4. Since the appropriability (or R\&D intensity) indicator and the focus of the territorial scope can affect the royalty rate in a multiplicative manner, we also use the following variables $($ aprmrkd $=a p r \times m r k j \times t i m e 4$ and $r d s m r k d=r d s \times m r k j \times t i m e 4)$.

\section{Estimation results}

Table 4 shows nine estimation results. Estimation 1 is the benchmark estimation with no pro-patent dummies. Estimations 2 to 6 use the appropriability indicator of patent (apr) to capture the impact of stronger IPR policy of Japan in late 1990s. We drop the variable (initial) in estimation 5 in order to check the robustness of the estimation results with respect to treating that variable as one component of the random error. We drop both industry and time dummies in estimation 6 to assess the industry fixed effects. Estimations 7 to 9 use the R\&D intensity $(r d s)$ instead of the appropriability indicator of patent (that is, we expect that the coefficient of $r d s$ increased from 1994 to 1998 due to the policy effect). The appropriability and the territorial restriction variables affect royalty in a multiplicative manner in the specification for estimations 2 and 7, while they do so in an additive manner for estimations 3 and 8 . On the other hand only the appropriability variable affects royalty in the specification for estimations 4 and 9 . Our preferred estimation is estimation 2 that has the largest likelihood. The tables omit reporting the estimated coefficients of the industry dummies and time dummies.

(Table 4)

R\&D intensity $(r d s)$ has a positive and highly significant coefficient at the $1 \%$ level in all 
estimations. Thus, higher R\&D intensity over time has resulted in higher incidence of high-royalty contracts, fully consistent with our expectation. The share of exclusive rights (monopoly) also has a positive coefficient in all estimations, consistent with the idea that exclusivity increases royalty rate. Its significance, however, is not stable across estimations. It is significant at the $5 \%$ level in our preferred estimation 2 , and it becomes highly significant (1\% level) when we drop the variable initial (estimation 5), due to a relatively high correlation between the two variables (see Table A-3). The declining incidence of monopoly rights over time should have affected negatively the incidence of high-royalty contracts.

As for the impact of IPRs, the brand variable $(b r)$ has the largest and most significant coefficient. It is significant at $1 \%$ level in all estimations based on the appropriability indicator of patents, except for estimation 6 . The significant increase in the incidence of trademark licensing over time should have significantly increased the incidence of high-royalty contracts. The other IPR variables (pat and know-how) also have positive coefficients, except for estimation 6 . The patent variable has a significant coefficient at the $5 \%$ level in our preferred estimation 2 . The finding that the expansion of trademarks is associated with the most significant increase in the incidence of high royalty contracts may not be surprising, given that a licensing contract with trademarks would enable a licensee to market a distinctive product with an internationally recognized brand, which would in turn indicate that the technology and the other assets licensed are comprehensive.

The comparison of estimations 2 and 6 demonstrates the importance of controlling for industry fixed effects to avoid estimation bias. In estimation 6 the patent variable has a significantly negative coefficient and the variable initial has a positive (although not significant) coefficient. Both of these results are likely due to the correlation between missing variables and the error term. For an example, the negative coefficient of a patent variable is driven by the fact 
that the royalty rate is high in the computer industry where patents used to be unimportant.

The cross-license variable ( $c r)$ has a significant and positive sign in all estimations, excluding estimation 6 . This finding suggests that this variable indicates the quality change of a licensed technology more than the change of the payment in kind. The incidence of a cross-licensing provision, therefore, helps us to control the change in the quality of the technology in a sector over time. The initial variable has a negative coefficient, as expected. Its exclusion does not significantly affect the estimation results, as shown in estimation 5.

All estimations, excluding estimation 9, show that the appropriability variable in 1995-98 has a positive and significant coefficient (1\% or 5\% level), whether in a multiplicative manner or in an additive manner with the territorial focus variable of a contract. It is significant at the $1 \%$ level in all estimations based on the appropriability indicator of a patent. That is, high royalty contracts increased significantly more in the industries for which IPRs are important. In the additive specification (estimation 3 and 8), the territorial focus variable has a positive coefficient but is significant only in estimation 8 . The comparison between estimations 2 and 4 (or between estimations 7 and 9) shows that the appropriability variable multiplied by the territorial focus variable (aprmrkd or $r d s m r k d$ ) has a slightly better explanatory power than the appropriability variable alone (aprd or $r d s d$ ). Thus, we have some evidence that the appropriability role of IPRs and the territorial restriction in the Japanese market specified in the contracts affect royalty in a multiplicative manner. These results support the view that the increase in high-royalty contracts in the latter part of the 1990s reflected the impact of stronger IPR policy in Japan.

\section{Conclusions}

We first reviewed the Japanese policy for stronger IPRs protection in the 1990s, focusing on the expansion of the patentable subject matter, restriction of the possibility of compulsory licensing, 
stronger deterrence against infringement, and the introduction of the doctrine of equivalents. It was concluded that there have been substantive changes in Japan's IPR policies. We then evaluated econometrically how stronger protection of IPRs in Japan had affected the incidence of high-royalty technology import contracts in the 1980s and 1990s.

Our econometric estimation based on sector-level panel data suggested that, controlling for industry fixed effects and period specific effects, higher R\&D intensity of domestic industry, trademark licensing and cross-licensing are accompanied with more high royalty contracts. Exclusivity also tends to increase the incidence of high-royalty contracts. A stronger effect of trademark licensing than patent and know-how licensing suggests that trademark licensing implies a larger commitment of a licensor. A positive effect of cross-licensing seems to suggest that the higher frequency of cross-licensing contracts indicates licensing of higher quality technology.

Our estimations also suggest that, controlling for these factors, the share of high royalty contracts increased significantly in the latter part of 1990s in the industries for which IPRs are important for appropriability. There is also some evidence showing that this effect is stronger in sectors in which the restriction of sales territory to Japan is frequently imposed in the contracts. The econometric results thus support the view that Japan has significantly strengthened its IPR protection. The results highlight the importance of the differential impacts of IPR policy according to the effect of IPRs on appropriability.

\section{Acknowledgments}

I would like to thank for valuable comments made by Gary Saxonhouse, Keith Head, Koichi Hamada, Hiroyuki Odagiri, Fukunari Kimura and the other participants in the Conference on International Economic Relations and Structural Change: Issues and Policy Options for Japan 
and the United States organized by the University of Michigan and Hitotsubashi University. I would like to thank Akira Goto and Akiya Nagata for enabling me to use their survey results on the indicator of the effectiveness of patent protection in the appropriation of R\&D (Goto and Nagata(1996)) for significantly extending Nagaoka (2003), on which the second part of this paper is based.

\section{References}

Anand, B.N., Khana, T., 2000. The structure of licensing contracts, J. Ind. Econ. 48, 103-135

Arora A., Fosfuri, A., Gambardella, A., 2001. Markets for Technology. MIT Press, Cambridge.

Arrow, K, 1962. Economic Welfare and the Allocation of Resources for Invention. In: R. Nelson (Ed.), The Rate and Direction of Inventive Activity. Princeton University Press, Princeton.

Caves, R., Crookell, H., Killing, P.J., 1983. The Imperfect Market for Technology Licenses, Oxf. Bull. Econ. \& Stat., 45, 249-267.

Cohen, W., Nelson, R., Walsh, J., 2000. Protecting Their Intellectual Assets: Appropriability Conditions and Why U.S. Manufacturing Firms Patent (or Not). NBER working paper No. W7552.

Goto A., Nagata, A., 1996. Study of innovation process by a survey data. Presented at the Workshop on Appropriability and Technological Opportunities at National Institute for Science and Technology Policy.

Merges, R. P., 1996. A Comparative Look at Intellectual Property Rights and the Software Industry. In: D. C. Mowery (Ed.), The International Software Industry. Oxford University Press.

Nagaoka S., 2003. Raisensu keiyaku kara mita puropatento seisaku no eikyo (Impact of 
'Pro-patent Policy' as Revealed in License-contracts). In: Goto, A., Nagaoka, S. (Eds.), Chiteki zaisan seido to inobeshon (Intellectual Property Rights and Innovation). Univ. of Tokyo Press, Tokyo.

Taylor, C., Silbertson, Z., 1973. The Economic Impact of the Patent System: A Study of the British Experience. Cambridge University Press, New York.

Schankerman M., Scotchmer, S., 1999. Damages and injunctions in the protection of proprietary research tools. NBER working paper 7086. 


\section{Appendix 1-Data Sources}

The licensing contracts data set is from the annual reports on the status of technology imports and technology-related imports compiled by the Science and Technology Agency (now by the National Institute for Science and Technology Policy). The tables with detailed industrial classification (39 industries) are available for 1981 to 1998, except for 1987 and 1988. The agency has compiled this report based on compulsory reporting requirements by the "Foreign Exchange and Foreign Trade Control Law" (hereinafter referred to as the "Foreign Exchange Control Law”).

The R\&D data are from the National Survey of Research and Development by the Ministry of Public Management, Home Affairs, Posts and Telecommunications. Since the data published from this survey are less aggregated than the license data in terms of industrial classification, the matching is imperfect in general machinery and electrical/electronics machinery.

We use the survey results on the contribution of patents in appropriating the return from R\&D by Japanese industries (Goto and Nagata (1996)) as an indicator of appropriability based on patent $(a p r)$. For six sectors which the survey did not cover, we estimated the indicators based on the R\&D intensity in these sectors. 
Table 1

Investments in tangible assets vs. in intangible assets (2000FY)

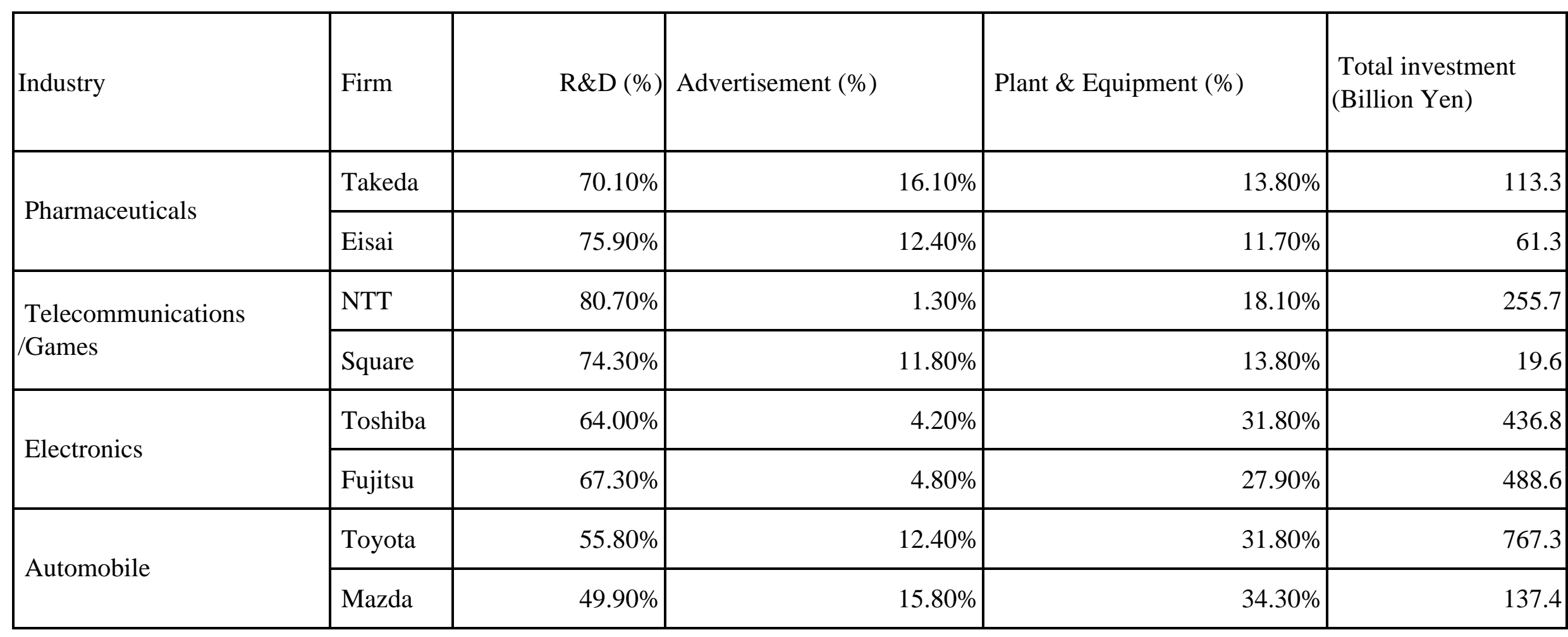

Note 1 . Total Investments=R\&D+Advertisements+Plant\&Equipment Investments

2. Non-consolidated basis

Data Source: NEEDS 
Table 2

Contract characteristics over time

\begin{tabular}{|c|c|c|c|c|c|c|c|c|c|}
\hline \multirow{2}{*}{\multicolumn{2}{|c|}{ The proportion in the contracts (\%) }} & \multicolumn{4}{|c|}{ I: Average of all contracts } & \multicolumn{4}{|c|}{ II. Average of 48 industry averages } \\
\hline & & $81-84$ & $85,86.89$ & $90-94$ & $95-98$ & $81-84$ & $85,86,89$ & $90-94$ & $95-98$ \\
\hline \multirow{4}{*}{ price } & $\begin{array}{l}\text { Contracts with financial } \\
\text { payment }\end{array}$ & 94.0 & 94.5 & 94.2 & 94.5 & 93.3 & 92.6 & 93.9 & 95.9 \\
\hline & Royalty contracts & 68.7 & 50.3 & 56.0 & 62.2 & 73.3 & 63.4 & 70.1 & 71.9 \\
\hline & High royalty contracts ${ }^{1)}$ & 13.4 & 14.9 & 23.7 & 26.5 & 13.4 & 11.0 & 17.5 & 14.8 \\
\hline & Initial payments & 58.2 & 70.6 & 69.6 & 61.3 & 57.6 & 66.1 & 63.2 & 60.4 \\
\hline \multirow{2}{*}{ non-price } & Monopoly rights & 51.0 & 44.1 & 36.7 & 29.4 & 52.0 & 48.7 & 45.8 & 41.6 \\
\hline & Coss license & 4.0 & 3.5 & 2.7 & 4.1 & 4.4 & 4.7 & 4.1 & 5.6 \\
\hline
\end{tabular}

Note $1 . \%$ of high royalty contracts are with respect to the royalty contracts, not with respect to all contracts. 
Table 3

Structure of IPRs over time

\begin{tabular}{|l|r|r|r|r|r|r|r|r|}
\hline \multirow{2}{*}{$\begin{array}{l}\text { The proportion in the contracts } \\
\text { (\%) }\end{array}$} & \multicolumn{4}{|c|}{ I: Average of all contracts } & \multicolumn{3}{c|}{ II. Simple average of industry values } \\
\cline { 2 - 9 } & \multicolumn{1}{|c|}{$11.71 \%$} & $10.38 \%$ & $8.15 \%$ & $9.01 \%$ & $14.35 \%$ & $15.50 \%$ & $12.46 \%$ & $15.42 \%$ \\
\hline Only patents & $36.47 \%$ & $33.89 \%$ & $24.30 \%$ & $23.96 \%$ & $41.08 \%$ & $44.04 \%$ & $44.23 \%$ & $43.06 \%$ \\
\hline With patents & $5.90 \%$ & $9.01 \%$ & $12.01 \%$ & $19.44 \%$ & $6.80 \%$ & $11.25 \%$ & $19.95 \%$ & $17.69 \%$ \\
\hline Wnly trademark & $24.20 \%$ & $21.49 \%$ & $21.01 \%$ & $32.39 \%$ & $23.61 \%$ & $25.87 \%$ & $31.04 \%$ & $38.51 \%$ \\
\hline Only knowhow & $48.78 \%$ & $52.84 \%$ & $59.20 \%$ & $48.71 \%$ & $41.66 \%$ & $36.20 \%$ & $32.09 \%$ & $28.96 \%$ \\
\hline With knowhow & $69.34 \%$ & $73.05 \%$ & $90.04 \%$ & $70.97 \%$ & $72.42 \%$ & $73.06 \%$ & $74.02 \%$ & $60.36 \%$ \\
\hline
\end{tabular}




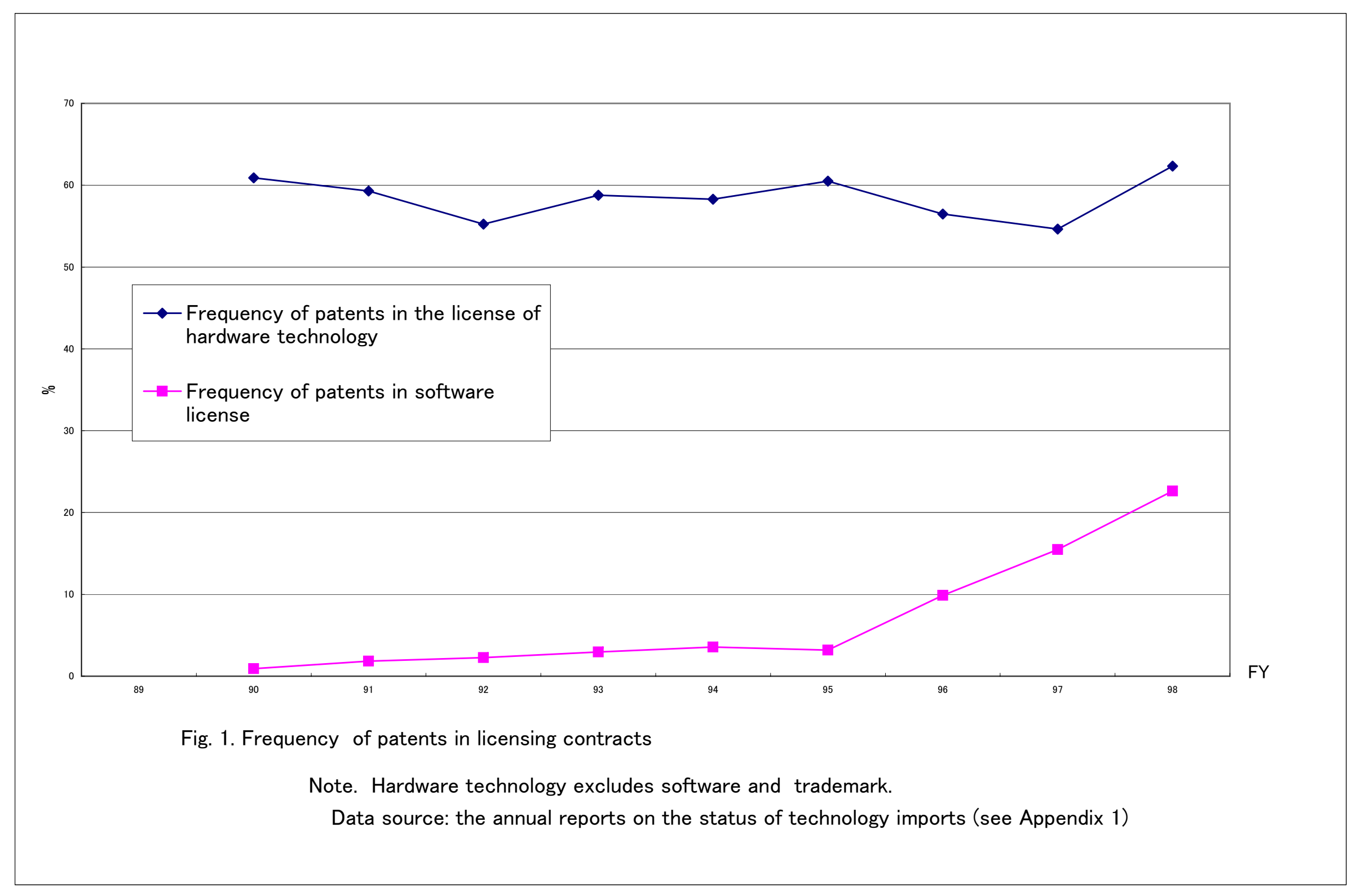




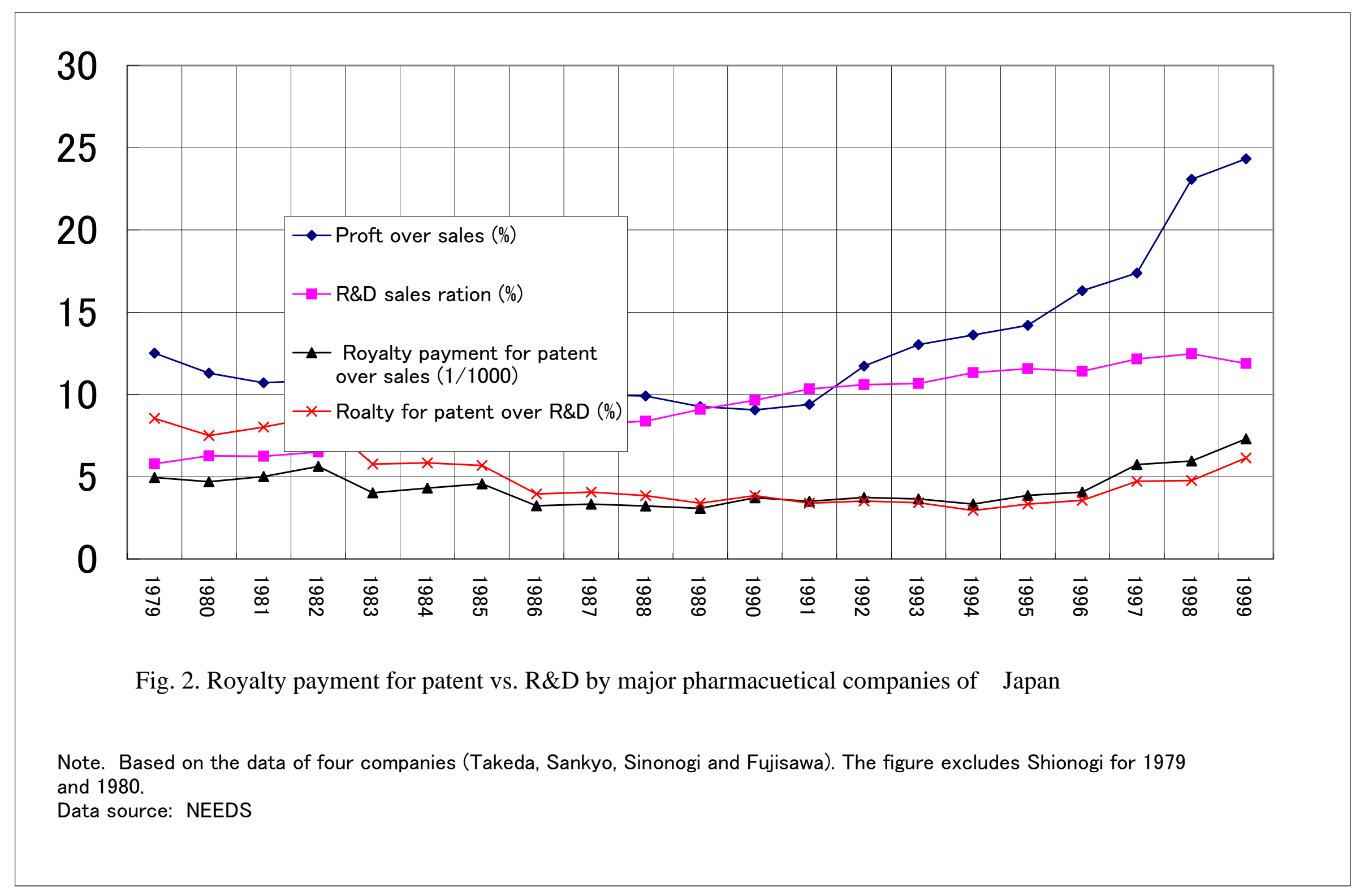




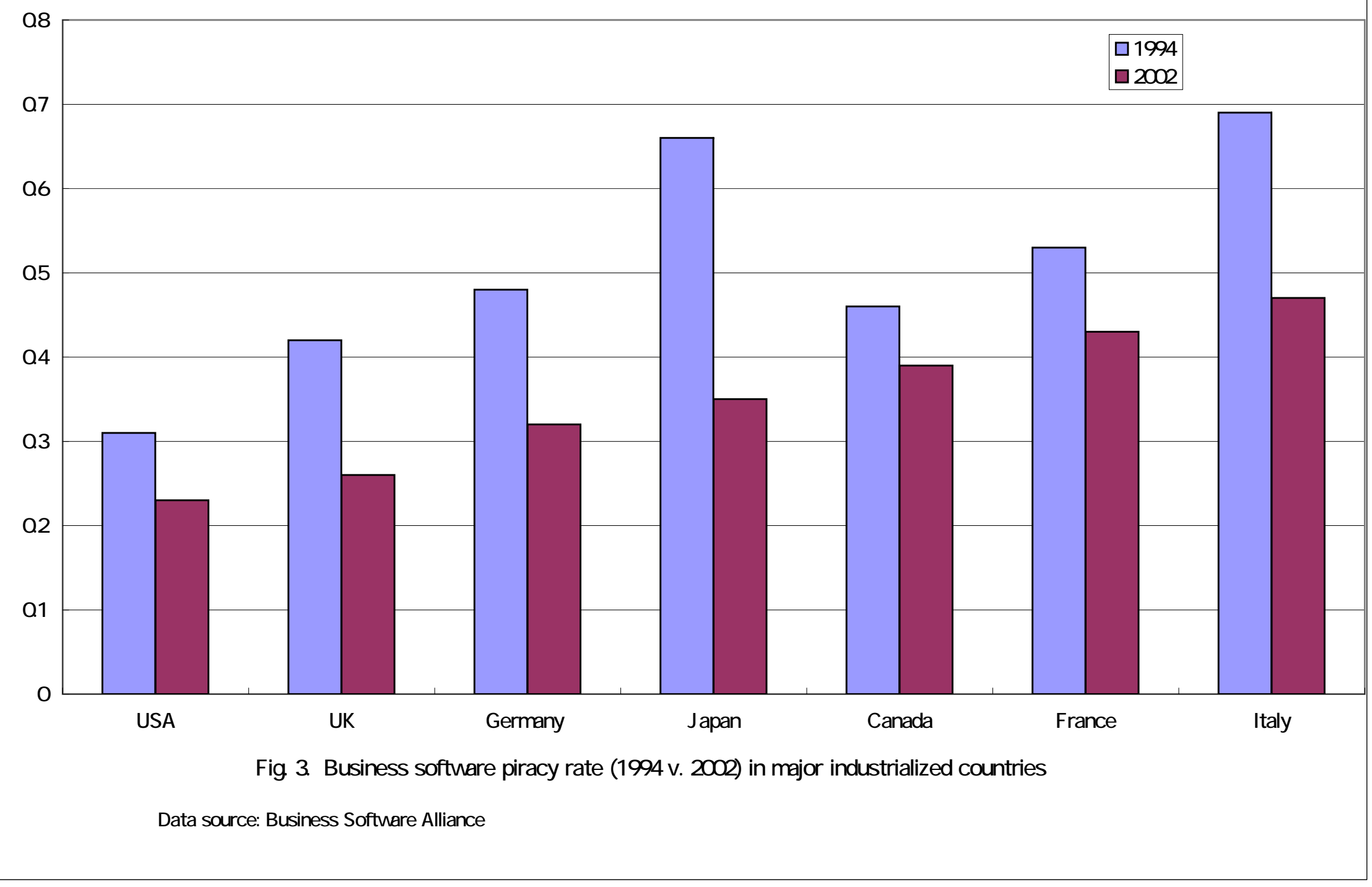




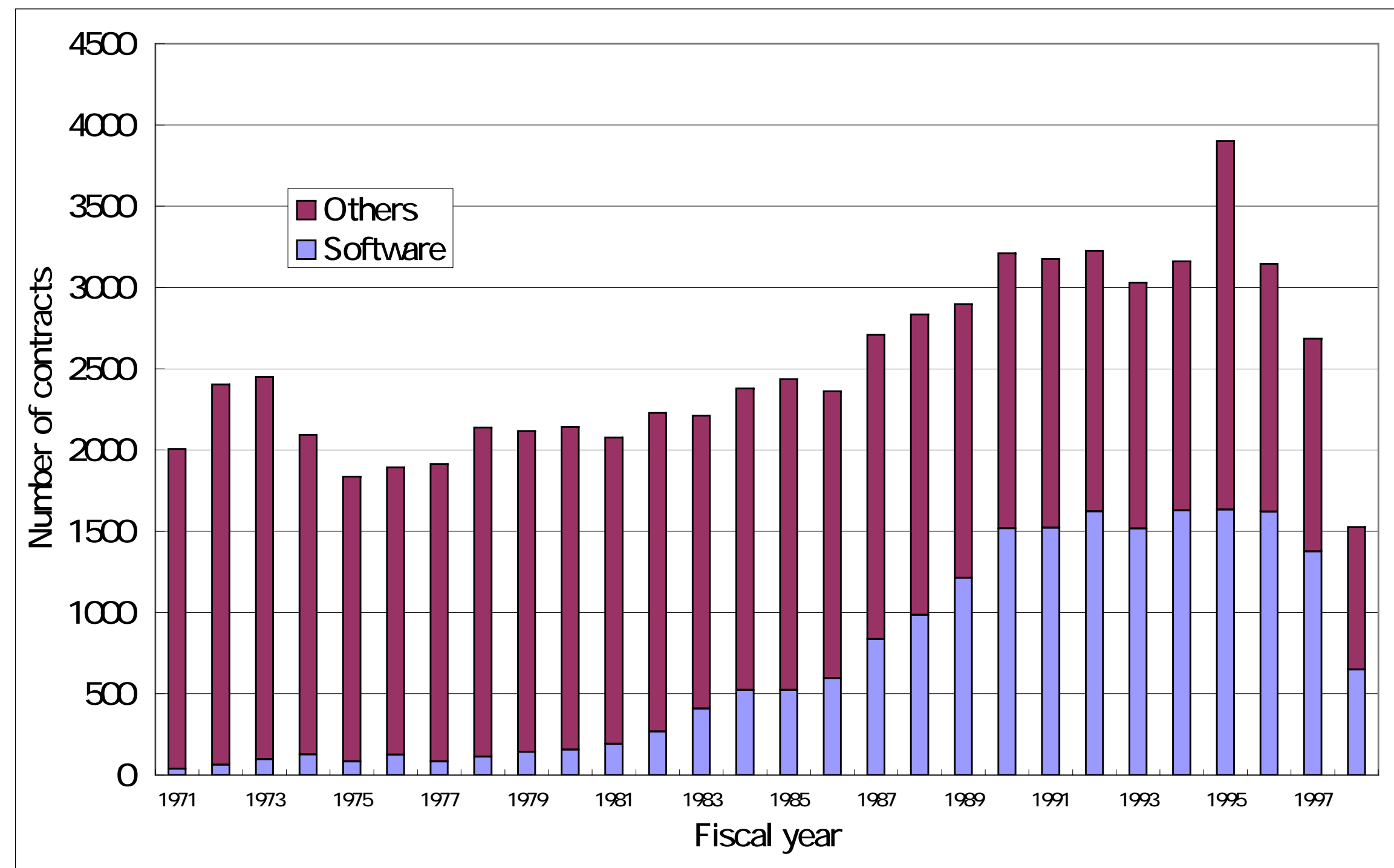

Fig. 4. Number of technology import contracts 
Table A-1

Industry composition of technology import contracts (\%)

\begin{tabular}{|l|r|r|r|r|}
\hline & \multicolumn{1}{|l|}{$81-84$} & $85,86,89$ & \multicolumn{1}{l|}{$90-94$} & \multicolumn{1}{l|}{$94-98$} \\
\hline Total number of contracts & 8,895 & 7,695 & 15,800 & 11,258 \\
\hline Clothing and textile products & $11.7 \%$ & $8.0 \%$ & $5.3 \%$ & $12.6 \%$ \\
\hline Drugs and medicines & $3.2 \%$ & $3.9 \%$ & $3.3 \%$ & $2.8 \%$ \\
\hline Other chemicals & $5.8 \%$ & $5.0 \%$ & $2.8 \%$ & $2.1 \%$ \\
\hline General machinery and tools & $18.8 \%$ & $12.6 \%$ & $8.0 \%$ & $7.3 \%$ \\
\hline Transportation equipment & $3.7 \%$ & $3.9 \%$ & $2.1 \%$ & $1.8 \%$ \\
\hline Computers & $17.4 \%$ & $32.9 \%$ & $53.0 \%$ & $46.7 \%$ \\
\hline Other electric/electronics machinery & $11.7 \%$ & $11.8 \%$ & $11.6 \%$ & $13.4 \%$ \\
\hline Precision machinery & $2.9 \%$ & $2.5 \%$ & $2.3 \%$ & $1.7 \%$ \\
\hline Others & $24.8 \%$ & $19.5 \%$ & $11.7 \%$ & $11.6 \%$ \\
\hline
\end{tabular}


Table A-2

Industry characteristics of licensing (average of the four periods), \%

\begin{tabular}{|c|c|c|c|c|c|c|c|}
\hline \multirow[t]{2}{*}{ Code } & \multirow[t]{2}{*}{ Industry } & \multirow{2}{*}{ 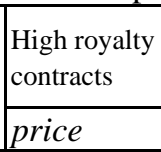 } & \multirow{2}{*}{\begin{tabular}{|l}
$\begin{array}{l}\text { Onerous } \\
\text { contracts }\end{array}$ \\
notfree \\
\end{tabular}} & \multirow{2}{*}{\begin{tabular}{|l} 
initial \\
initial \\
\end{tabular}} & \multirow{2}{*}{\begin{tabular}{|c|}
$\begin{array}{l}\text { territorial } \\
\text { restriction to } \\
\text { Japan }\end{array}$ \\
$m r k j$ \\
\end{tabular}} & \multirow{2}{*}{\begin{tabular}{|l} 
R\&D \\
intensity
\end{tabular}} & \multirow[t]{2}{*}{ sample } \\
\hline & & & & & & & \\
\hline 4 & Construction & $\begin{array}{r}8.6 \\
\end{array}$ & 100.0 & 66.3 & $88.1 \%$ & 0.48 & $* *$ \\
\hline 11 & Food and tobacco & 4.8 & 89.3 & 41.2 & $81.7 \%$ & 0.87 & $*$ \\
\hline 12 & Textiles & 17.0 & 96.6 & 28.3 & $78.2 \%$ & 1.50 & $*$ \\
\hline 14 & Outer garments & 8.9 & 98.6 & 27.0 & $82.3 \%$ & 1.50 & $* *$ \\
\hline 15 & Other clothing textile products & 14.1 & 99.2 & 11.8 & $96.8 \%$ & 1.50 & ** \\
\hline 16 & $\begin{array}{l}\text { Sawing/planing mill products, wood products and } \\
\text { furniture }\end{array}$ & 5.2 & 96.8 & 46.8 & $85.0 \%$ & & \\
\hline 17 & Pulp and paper & 17.6 & 93.8 & 53.0 & $81.3 \%$ & 0.79 & $*$ \\
\hline 22 & Industrial organic chemicals & 5.2 & 90.1 & 74.7 & $42.5 \%$ & 3.50 & $*$ \\
\hline 24 & Oil \& fat products, soaps, etc. & 10.6 & 91.6 & 51.0 & $77.8 \%$ & 3.76 & $*$ \\
\hline 25 & Drugs and medicines & 24.1 & 87.6 & 72.4 & $56.5 \%$ & 7.35 & $*$ \\
\hline 26 & Other chemicals & 16.0 & 86.2 & 49.4 & $60.7 \%$ & 4.14 & $*$ \\
\hline 31 & Rubber products & 13.3 & 94.1 & 42.4 & $40.0 \%$ & 3.03 & $*$ \\
\hline 32 & Tanned leather, leather products and fur skins & 15.8 & 99.2 & 16.8 & $90.4 \%$ & & \\
\hline 33 & Ceramics & 14.4 & 93.6 & 68.1 & $50.0 \%$ & 2.43 & $*$ \\
\hline 35 & Non-ferrous metals and products & 7.9 & 89.1 & 78.7 & $43.8 \%$ & 1.98 & $*$ \\
\hline 36 & Fabricated metal products & 8.4 & 95.6 & 65.1 & $49.3 \%$ & 1.44 & $*$ \\
\hline 41 & Boilers and engines & 5.3 & 94.3 & 89.7 & $87.0 \%$ & 2.92 & $*$ \\
\hline 42 & $\begin{array}{l}\text { Agricultural, construction and mining machinery and } \\
\text { equipment }\end{array}$ & 8.6 & 98.7 & 64.0 & $25.0 \%$ & 2.92 & * \\
\hline 43 & Metal working machinery & 6.4 & 95.6 & 70.8 & $43.1 \%$ & 2.92 & $*$ \\
\hline 45 & Special industrial machinery & 17.1 & 97.2 & 65.7 & $32.0 \%$ & 2.92 & $*$ \\
\hline 47 & Pumps, compressors and blowers & 5.4 & 97.1 & 64.5 & $33.3 \%$ & 2.92 & $*$ \\
\hline 48 & Prime mover & 2.3 & 95.8 & 61.2 & $24.2 \%$ & 2.92 & $*$ \\
\hline 49 & Chemical machinery and equipment & 13.2 & 98.2 & 76.1 & $55.9 \%$ & 2.92 & $*$ \\
\hline 50 & Other general industry machinery & 9.5 & 99.0 & 75.8 & $42.9 \%$ & 2.92 & $*$ \\
\hline 51 & Other machinery & 11.6 & 92.8 & 72.4 & $36.2 \%$ & 2.92 & ** \\
\hline 52 & Transportation equipment & 12.1 & 96.7 & 72.1 & $52.9 \%$ & 3.23 & $*$ \\
\hline 53 & Precision machinery & 25.0 & 94.1 & 58.6 & $43.4 \%$ & 4.99 & $*$ \\
\hline 61 & $\begin{array}{l}\text { Electricity generation, transmission \& distribution } \\
\text { equipment and industrial electrical machinery, } \\
\text { equipment \& supplies }\end{array}$ & 12.6 & 93.1 & 70.6 & $37.8 \%$ & 5.21 & $*$ \\
\hline 64 & Wired and radio communication equipment & 9.1 & 92.2 & 82.9 & $15.2 \%$ & 5.61 & $*$ \\
\hline 65 & $\begin{array}{l}\text { Radio \& television receivers and electric audio } \\
\text { equipment }\end{array}$ & 3.0 & 90.2 & 63.1 & $8.3 \%$ & 5.61 & $*$ \\
\hline 68 & Computers & 62.8 & 95.7 & 78.2 & $71.9 \%$ & 5.61 & $*$ \\
\hline 69 & Other electronic equipment & 10.5 & 92.9 & 76.7 & $10.7 \%$ & 5.61 & $* *$ \\
\hline 70 & Electronic parts and devices & 8.0 & 88.9 & 75.3 & $12.5 \%$ & 5.61 & $*$ \\
\hline 71 & Other electric machinery & 3.7 & 94.0 & 78.8 & $17.6 \%$ & 5.61 & $* *$ \\
\hline 81 & Precious metal products, costume jewelry, etc. & 25.9 & 94.0 & 16.8 & $68.2 \%$ & & \\
\hline 82 & Leisure activity equipment & 19.2 & 93.4 & 40.6 & $66.7 \%$ & & \\
\hline 83 & Plastic products & 5.7 & 89.7 & 65.9 & $52.2 \%$ & & \\
\hline 84 & Manufacturing industries not classified elsewhere & 27.9 & 94.8 & 44.3 & $88.2 \%$ & & \\
\hline 90 & Other industries & 12.6 & 96.8 & 62.8 & $100.0 \%$ & & \\
\hline
\end{tabular}

Note 1 . The proportion of the contracts with the territorial restriction to Japan (mrkj) is based on the contracts in 90 and 91.

Note 2. Appropriability index is estimated based on the R\&D intensity for the sectors with **. 
Table A-3

Summary Statistics

\begin{tabular}{|c|c|c|c|c|c|c|c|c|c|c|c|c|c|c|c|c|}
\hline \begin{tabular}{|l|} 
Variable \\
\end{tabular} & Obs & Mean & Std. Dev. & Min & Max & price & rds & monopoly & br & pat & kh & $\mathrm{cr}$ & initial & aprd & mrkd & aprmrkd \\
\hline price & 128 & \begin{tabular}{|l|}
12.40 \\
\end{tabular} & 11.96 & 0 & 71.1 & 1 & & & & & & & & & & \\
\hline rds & 128 & 3.36 & 1.79 & 0.43 & 8.28 & 0.252 & 1 & & & & & & & & & \\
\hline monopoly & 128 & 47.35 & 22.60 & \begin{tabular}{|l|}
2.1 \\
\end{tabular} & 93.9 & -0.026 & -0.460 & 1 & & & & & & & & \\
\hline br & 128 & 19.27 & 20.34 & 0.47 & 96.3 & 0.079 & -0.288 & 0.286 & 1 & & & & & & & \\
\hline pat & 128 & 42.61 & 22.32 & 0.2 & 90.8 & -0.301 & 0.501 & -0.407 & -0.442 & 1 & & & & & & \\
\hline $\mathrm{kh}$ & 128 & 73.59 & 20.54 & 4.8 & 100 & 0.001 & $\begin{array}{l}-0.047 \\
\end{array}$ & 0.066 & -0.760 & 0.096 & 1 & & & & & \\
\hline $\mathrm{cr}$ & 128 & 4.96 & 5.15 & 0 & 26.5 & -0.103 & 0.341 & -0.524 & -0.321 & 0.336 & -0.020 & 1 & & & & \\
\hline initial & 128 & 63.30 & 19.75 & 3.4 & 92.7 & -0.044 & 0.427 & -0.485 & -0.771 & 0.528 & 0.604 & 0.355 & 1 & & & \\
\hline aprd & 32 & 30.07 & 6.89 & 18.44 & 54.61 & 0.507 & 0.580 & 0.093 & -0.220 & 0.138 & 0.161 & 0.071 & 0.212 & 1 & & \\
\hline mrkd & 32 & 0.49 & 0.25 & 0.08 & 0.97 & 0.214 & -0.571 & 0.175 & 0.399 & \begin{tabular}{ll|}
-0.761 \\
\end{tabular} & -0.233 & -0.422 & -0.532 & -0.048 & 1 & \\
\hline aprmrkd & 32 & 14.75 & 8.24 & 2.11 & $\begin{array}{ll}35.78 \\
\end{array}$ & 0.478 & -0.178 & 0.167 & 0.224 & $\begin{array}{l}-0.603 \\
\end{array}$ & -0.086 & -0.326 & -0.338 & 0.471 & 0.845 & 1 \\
\hline
\end{tabular}

Note The means and the correlations of aprd 、 mrkd and aprmrkd are calculated only for the most recent period from 1994 to 1998.

\begin{tabular}{|c|c|c|c|c|c|c|c|c|c|}
\hline & & Mean & & & & & & & \\
\hline & $\begin{array}{l}\mathrm{N} \text { of } \\
\mathrm{ob}\end{array}$ & price & initial & $r d s$ & monopoly & $b r$ & pat & $k h$ & $c r$ \\
\hline 1981-84 & 32 & 12.17 & 58.76 & 2.60 & 52.97 & 11.22 & 39.52 & 80.82 & 5.19 \\
\hline $1985,86,89$ & 32 & 10.37 & 69.60 & 3.33 & 50.28 & 14.82 & 43.29 & 75.61 & 4.62 \\
\hline $1990-94$ & 32 & 12.97 & 63.82 & 3.73 & 47.35 & 24.53 & 43.85 & 69.35 & 4.18 \\
\hline 1995-98 & 32 & 14.10 & 61.01 & 3.79 & 38.78 & 26.51 & 43.77 & 68.58 & 5.84 \\
\hline
\end{tabular}

